\title{
Educational-industrial cluster for development of youth entrepreneurship
}

\author{
Alexey Chernitsov ${ }^{1}$, Iuliia Artamonova ${ }^{1, *}$, and Daniil Osipov ${ }^{2}$ \\ ${ }^{1}$ Penza State University of Architecture and Construction, Titova Str., 28, 440028, Penza, Russia \\ ${ }^{2}$ Astrakhan State University, Tatishchev Str. 20A, 414000, Astrakhan, Russia
}

\begin{abstract}
The purpose of the research is to develop theoretical and methodological approaches, as well as practical guidance for the production and education cluster in the construction sector of the Penza Region, Russia as it is an effective tool for the development of youth entrepreneurship. The article discusses the theory of the education clusters, the definition and peculiarities of the production and education cluster, as well as the factors of the production and education cluster development in the construction sector. The authors analyze the challenges that should be overcome within the framework of the development of the production and education cluster. They also describe the effects from the interaction of all cluster members. The article reviews and evaluates the activities of Russian and foreign education clusters. It defines the goals for the industrial cluster and presents a model for the strategic development of the production and education cluster in the construction sector of the Penza Region.
\end{abstract}

\section{Introduction}

The distinctive features of modern economy are speed, flexibility and ability to interact in an environment of innovation and economic growth.

Clusters and smart specialization in the regions are the hubs of economic growth and the basis for the regional economic development.

In the Russian and foreign literature, much attention is paid to the concept and definition of the cluster, its structure and forms. Much is also written about the cluster development based on the region's smart specialization that is a practice of moving from simple groups of organizations and state institutions to integrated and innovative cluster systems. The smart specialization approach means that small, risk-free projects should be implemented at first and the subsequent effective joint activities that increase the cluster's competitiveness will follow after them.

Nowadays the methods of cluster development have been approved at the legislative level, but despite this, incorrect identification of the cluster is often observed. For instance, scientific or technological parks; special economic zones; industrial, trade or professional associations; consortia, alliances, network structures of firms, cooperatives are misclassified as clusters [1].

\footnotetext{
* Corresponding author: clusterwings@mail.ru
} 
Each of these entities is not a cluster separately, but it can become an important element in a cluster.

Thus, it can be said that the cluster is an association or network of competing entities that collaborate on their economic activities at a certain geographic area and develop and implement cluster initiatives.

\section{Method}

Analysis of European cluster policy was made in 31 countries and it showed that 26 countries had national cluster programs, and cluster policy was a part of innovation policy.

Cluster policy began to be widely implemented in the regions of Russia. More than 100 industrial clusters have been created in the Russian Federation in less than five years that is a major breakthrough in cluster development [2]. The Penza Region has been actively involved in the process of cluster development, and currently there are 7 clusters in the region: confectionery, instrument-making, glass, IT, furniture, biomedical, tourist clusters.

The peculiarity of cluster development in the Penza Region is the elaboration of its own practical experience as there are no best Russian practices [3].

At present, significant methodologies have been developed on the problem of regional cluster development. The processes of innovation activities in clusters, issues of intracluster interaction are investigated. At the same time many questions remain open, in particular, the problem of developing an integrated cluster policy in the region that covers all sectors with the potential for cluster development. This policy should consider the territorial and sectoral peculiarities of the regional development.

\section{Results}

To determine the direction of cluster development, first of all, it is necessary to examine the structure of the cluster and identify the main actors and stakeholders.

In due time, there comes an understanding that businesses cannot provide itself with all the necessary resources on their own, produce the widest range of products that completely covers the needs of the market. Understanding this fact, mainly based on trust, allows competitors to interact with each other in the fields and areas where their competition is lowered [4].

Supporting enterprises are enterprises that support businesses within the cluster specifically or by implication. Depending on the type of cluster business support may include the following range of suppliers: suppliers of raw materials; suppliers of equipment; component suppliers; packing companies.

Supporting enterprises also include providers of services, for example: banks and other suppliers of assets and equity financing, including seed funds, business angels, venture capital providers and investment banks in IPOs; accounting firms that are familiar with special needs of companies in a cluster; wage system management organizations; maintenance, testing, prototyping companies and firms; transport, logistics and warehousing service companies and firms; law firms working in the field of intellectual property protection and technology transfer; PR and marketing experts; recruitment agencies; management, design, market research, marketing and consulting [5-7].

In a cluster, the core enterprises and business support organizations work together with the cluster community. A wide range of actors of social infrastructure actively participates in successful clusters.

At present, there are different classifications or types of clusters (Fig. 1) [8]: 


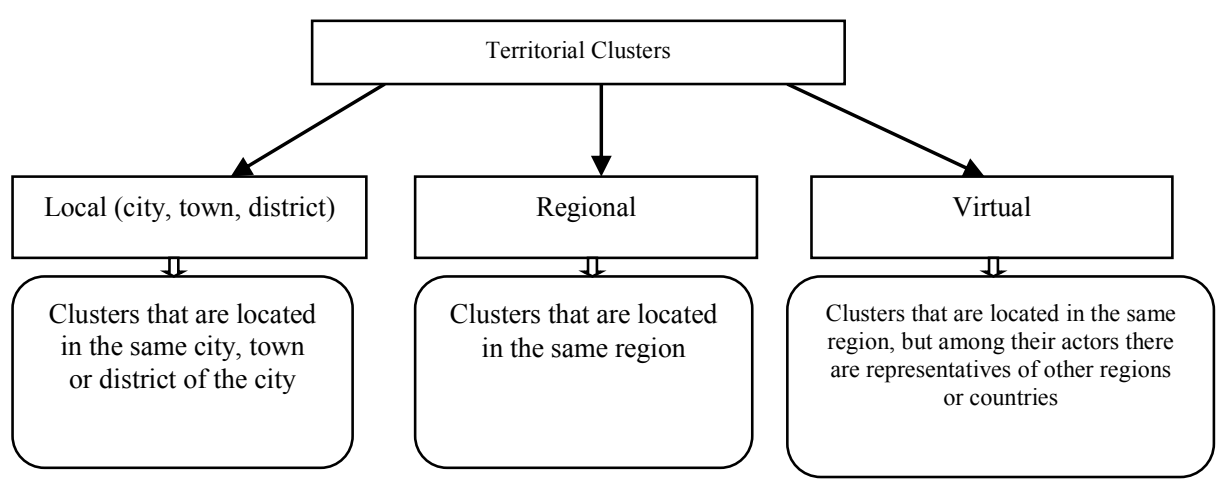

Fig. 1. Classification. Territorial Clusters.

If the region has a large area, there will be local clusters (Fig. 2):

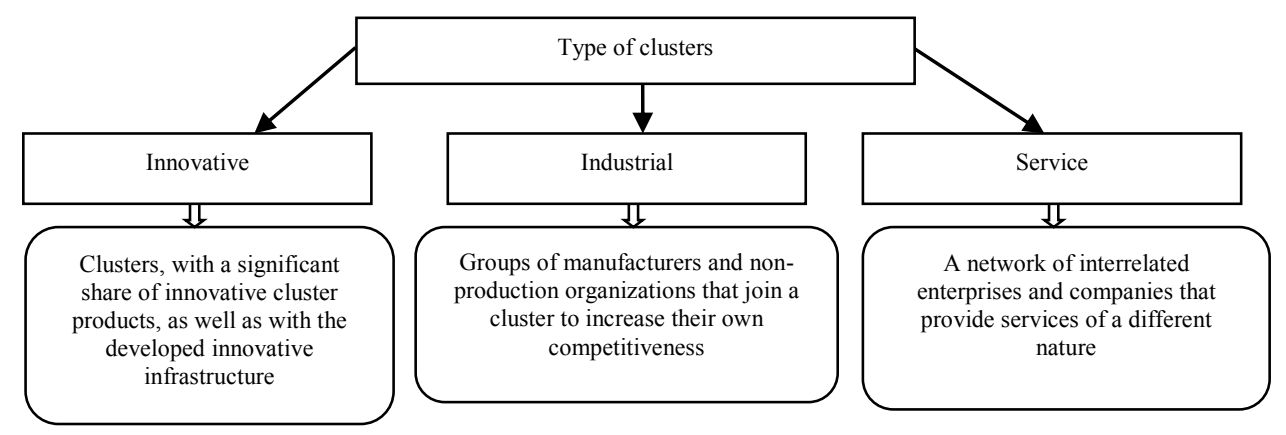

Fig. 2. Classification by cluster type.

Among the positive impacts of the cluster, it should be mentioned the increase of the level of professional development for the relevant industry.

There are effects of the professional development boost and innovative commercialization growth within the framework of the production and education cluster.

A production and education cluster is the core for the development of a continuous integrated educational system that includes different levels of professional education. This system is based on the continuity of educational programs. The educational programs are focused on needs of employers - horizontally (qualification level) and vertically (education level). The education cluster develops as a result of the joining efforts of various organizations (universities, institutions of initial and secondary vocational education, industrial companies, research centers, individual entrepreneurs, government bodies, public organizations, etc.).

Collaboration of all cluster members will be able to solve these problems and provide a number of effects. Educational institutions: improvement of the facilities of the educational institutions; encouragement of the professional growth of the teaching staff; on-the-job training and externship for students; competence of qualified professionals to target a modern labor market. Enterprises and companies: availability of highly qualified personnel; job placement by profession and high salaries in R\&D; increase in labor productivity; people who qualify to operate modern facilities and exploit technologies.

Regional authorities: decline in unemployment and social strain; increase in volume of taxes and dues to the regional and federal budgets (budgetary efficiency); development of 
small and medium businesses in the region; quality products and services (reducing the commodity shortage).

The production and education cluster can be integrated into a territorial cluster or exist independently. The forms of the production and education cluster development are presented in Table 1.

Table 1. Forms of production and education clusters.

\begin{tabular}{|c|c|c|c|}
\hline \multicolumn{4}{|c|}{ 1. By members: } \\
\hline $\begin{array}{l}\text { - Innovative type: } \\
\text { scientific organization is } \\
\text { included }\end{array}$ & \multicolumn{2}{|c|}{$\begin{array}{c}\text { - Cluster of Higher education: } \\
\text { core cluster member is a } \\
\text { university }\end{array}$} & $\begin{array}{l}\text { - Cluster of secondary } \\
\text { vocational education: } \\
\text { core cluster member is a } \\
\text { secondary vocational } \\
\text { education institution }\end{array}$ \\
\hline \multicolumn{4}{|c|}{ 2. By the level of development: } \\
\hline $\begin{array}{l}\text { - Proto clusters: } \\
\text { there are members in the } \\
\text { cluster, but there are no } \\
\text { connections between them }\end{array}$ & \multicolumn{2}{|c|}{$\begin{array}{l}\text { - Created: } \\
\text { close links between cluster } \\
\text { members }\end{array}$} & $\begin{array}{l}\text { - Developed: } \\
\text { close links and cluster } \\
\text { members fulfill joint projects }\end{array}$ \\
\hline \multicolumn{4}{|c|}{ 3. By integration into the industry: } \\
\hline \multicolumn{2}{|c|}{$\begin{array}{l}\text { - Independent cluster: } \\
\text { production and education cluster exists as } \\
\text { an independent unit }\end{array}$} & \multicolumn{2}{|c|}{$\begin{array}{l}\text { - Subcluster: } \\
\text { production and education cluster is integrated } \\
\text { into the territorial cluster }\end{array}$} \\
\hline \multicolumn{4}{|c|}{ 4. By territory: } \\
\hline \multicolumn{2}{|c|}{$\begin{array}{l}\text { - Regional: } \\
\text { production and education cluster is created } \\
\text { in the territory of a certain region }\end{array}$} & \multicolumn{2}{|c|}{$\begin{array}{l}\text { - Interregional: } \\
\text { production and education cluster is on the } \\
\text { territory covering several regions }\end{array}$} \\
\hline
\end{tabular}

Peculiarities of the production and education cluster development in the construction sector

The construction industry, like the Russian economy as a whole, faces long-term comprehensive challenges that reflect both world trends and internal barriers to development. The first challenge is the strengthening of global competition. The second challenge is a new wave of technology change intensifying innovations. A new technological base is being formed on the basis of biotechnologies, IT and nanotechnologies. The third challenge is the growing role of human capital as the main factor of economic development. The fourth challenge is the inefficiency of the rawmaterials export model of Russian economic development due to the unstable situation in the world energy market. It is necessary to shift funding from the budgetary to the investment market and attract financial resources from public. [9].

The production and education cluster can supply the construction sector with labor resources.

The peculiarities of the production and education cluster development in the construction sector are described below [10].

The analysis of the activity of successful education clusters makes it possible to identify the features of their development:

The core of the cluster is educational organizations that train personnel for the construction industry.

The structure of the construction and education cluster can include core members and support companies working in the economic, political and socio-cultural environment of the region. 
The basis of the production and education cluster is a complex of interdependent vocational education institutions that have strong links with their sector and have established partnerships with industry enterprises.

The production and education cluster development in the construction sector should be aimed at achieving a synergetic effect from the joint activities of all educational institutions. It can ensure awareness of the choice of vocational guidance for the youth and take to a new level the staffing of the construction sector.

The aim of the production and education cluster in the construction sector is to improve the quality of construction education, its forms and methods of personnel training for construction industries; to provide the sector with human resources in quantity, sufficient to ensure the timely completion of the construction of strategic real estate.

When interacting with each other, the cluster members obtain a greater benefit than from a simple co-operation. The social mobility of the student as a part of the cluster increases. Third, the labor market management system in the construction industry improves.

\section{Conclusion}

Analysis of the cluster policy of the Russian Federation in the current economic conditions made it possible to draw the following conclusions.

It is determined that clusters are an effective tool for economic development, they help businesses to achieve a synergistic effect on the basis of combining various resources, and provide demand for new technologies, personnel and finance.

Nowadays, almost every construction company has a shortage of personnel at some point (workers, engineers and technicians). The commercialization of innovations is also of particular interest due to the fact that private sector remains largely unresponsive to the results of innovation activity; there are no or small investments in intellectual property, innovation technologies are poorly adopted.

A well-argued assumption has been made that the upgrade of professional training and the innovation commercialization growth can be fulfilled within the framework of the production and education cluster.

The production and education cluster is a set of interrelated institutions of professional education, enterprises, industry associations and infrastructure that cooperate on industry basis and have partnership relations.

It is defined that the main goal of a production and education cluster development is to create conditions and provide the national economy with highly qualified personnel of various levels of professional education, and also to unlock the entrepreneurial potential of young people. The core of the production and education cluster is a complex of interdependent professional education institutions that have strong links with their sector and have established partnerships with industry enterprises.

The aim of the production and education cluster in the construction sector is to improve the quality of construction education, the forms and methods of personnel training for construction industries; to provide the sector with human resources in quantity, sufficient to ensure the timely completion of the construction of strategic real estate.

\section{Acknowledgments}

The research is made within the framework of Scientific Project No 18-410-580017 and supported by the Russian Fundamental Research Fund and the Government of the Penza Region. 


\section{References}

1. D.I. Streltsov, I.S. Artamonova, Fund.Res. 10-3, 625-629 (2015)

2. V.L. Abashkin, A.D. Boyarov, E.S. Kutsenko, Foresight-Russia 3-6, 16-27(2012)

3. I.S. Artamonova, P.V. Kolesnikov, Mod. Scient. Res. And innov. 4, 91-94 (2015)

4. Y. Morozyuk, A. Sharkova, I. Merkulina, O. Vasilyeva, Journal of Environmental Management and Tourism 8(3-19), 507-515 ( 2017)

5. A. Mottaeva, A. Zheltenkov, MATEC Web of Conferences 170, 01022 (2018) doi: 10.1051/matecconf/201817001022

6. E.S. Kutsenko, Foresight-Russia 1-9, 32-55 (2015)

7. G. Dyakova, S. Izmaylova, A. Mottaeva, E. Karanina, IOP Conf. Series: Earth and Environmental Science 90, 012218 (2017) doi :10.1088/1755-1315/90/1/012218

8. I. Artamonova, A. Chernitsov, D.Osipov, A. Tuskov, A. Konkin, J. Ponte 73-2, 34-46 (2017)

9. K. Kunanbayeva, A. Gorovoy, A. Butyrin, MATEC Web of Conferences 193, 05048 (2018)

10. E. Chibisova, Journal of International Scientific Publications: Economy \& Business 5(2), 17-29 (2015) 